\title{
Legal Certainty Value in Pre-Accusation Institute to Optimize Justice for Justice Seekers: Reconstruction of Pre-Accusation in the Criminal Procedure Code
}

\author{
Lia Pratiwi ${ }^{1}$ \\ University Padjadjaran, Faculty of Law, Bandung, INDONESIA
}

Received: 4 February 2020 • Accepted: 3 April 2020 • Published Online: 12 April 2020

\begin{abstract}
The pre-accusation institute is currently facing an extraordinary problem. The imbalance with the lack of communication between the investigation and the prosecutor is very obvious. Beside the legal vacuum must be how long and how many pre-prosecutions do. Between norms and the relationship and communication between law enforcement officers in the prosecution institution, it can cause the value of justice and legal certainty to be harmed, so that justice seekers receive treatment that does not respect the values of human rights. Concrete step as an effort to restore the function of this pre-prosecution institution is to carry out reconstruction of this institution. The consequence is fixing positive rules as in the Criminal Procedure Code, which can be implemented in the establishment of the Criminal Procedure Code Bill.
\end{abstract}

Keywords: pre-accusation, reconstruction, certainty and justice, human rights.

\section{Introduction}

Provisions before the entry into force of the Criminal Procedure Code, namely HIR (Het Herziene Inland Reglement) that the authority to investigate all criminal acts is a prosecutor (magistraat), while the police act as "assistant prosecutors" (hulp magistraat). ${ }^{2}$ In fact, it is clear in the HIR that the police are assistant prosecutors in the investigation process. This means that the investigative institution is fully under the authority and power of the prosecutor's office, so that in the body of the prosecutor's office there is a so-called Central Investigation Service that is headed by a police officer. ${ }^{3}$ However, in the current system, prosecutors only function as case file researchers and it is difficult to assess whether a case is included in the prosecution or not because the entire set of investigations is only carried out by the Police.

His friendship with the position of the Attorney General's Office (Procureur Generaal bij de Hoge Raad), which is under one roof together with the Supreme Court (MA). This position is reminiscent of the legal position (recht positie) of the Attorney General and the Attorney

\footnotetext{
${ }^{1}$ Doctorate Candidate in Law Science.

2 Andi Hamzah, Hukum Acara Pidana Indonesia, Sinar Grafika: Jakarta, 2010, 132.

3 Sutherweim, Dwi Windu Sejarah Kejaksaan, Kejaksaan RI: Jakarta, 1991.
}

(C) Authors. Terms and conditions of Creative Commons Attribution 4.0 International (CC BY 4.0) apply. Correspondence: Lia Pratiwi, University Padjadjaran, Faculty of Law, Bandung, INDONESIA. E-mail: liapratiwi2020@gmail.com. 
General's Office in the Netherlands which prevails until now. 4 Through the mechanism of the full authority of the investigation under the authority of the Prosecutor's Office, "pre-prosecution" institutions are not recognized. Coordination between investigators and prosecutors is personal and close because when investigations begin, prosecutors can be directly involved together with the police. This situation is similar to the investigations and prosecutions in force in the Corruption Eradication Commission (KPK), namely investigators and public prosecutors under one roof (current roof system) at this time. ${ }^{5}$ Since the enactment of the Criminal Procedure Code the criminal justice sub-system relations namely the Police, Prosecutors and Courts (Judiciary) apply compartmentalization, namely the source of the separation of powers and powers of investigation, prosecution and examination as well as verification in court. Or it can be said that there is a function differentiation ${ }^{6}$ in the Indonesian Criminal Justice System (SPP). As a consequence of functional differentiation, the activities of investigating general criminal offenses are entirely the duties and responsibilities of the police, while the prosecutor's office is in the prosecution. There is functional relationship. ${ }^{7}$ The police and prosecutors in investigating activities for prosecution are called pre-prosecution. ${ }^{8}$

The concept of functional differentiation, implies that the Criminal Justice System (SPP) in Indonesia, especially in the investigation and prosecution phase, is divided into compartments as excesses of the concept of functional differentiation. This boxing is reflected in the pre-prosecution mechanism. The prosecution mechanism is a coordination space between the investigator and the public prosecutor that must be taken after the investigator has finished conducting an investigation. Investigation results from investigators in the form of case files will be submitted to the public prosecutor for investigation. If the public prosecutor believes that the case file is complete, the process will proceed to the prosecution stage, but if the public prosecutor feels the case file is incomplete, the public prosecutor will provide instructions to the investigator in order to complete the case file. 9

This pretrial mechanism directly impacts the limited active role of the public prosecutor in following or directing the course of the investigation. The role of the public prosecutor is minimized to the extent of examining the results of the investigation, and giving

4 Tolib Effendi, Sistem Peradilan Pidana: Perbandingan Komponen dan Proses Sistem Peradilan Pidana di Beberapa Negara, Pustaka Yustisia: Yogyakarta, 2013.

5 Raja Mohamad Rozi, Revitalisasi Lembaga Pra Penuntutan Guna Menyokong Kepastian Hukum \& Keadilan Dalam Sistem Peradilan Pidana Indonesia. Rechvinding, Volume 6, Number 1, April 2017, 90.

${ }^{6}$ The concept of functional differentiation (different functions) is adopted in the Criminal Procedure Code, among law enforcement components that carry out functions related to judicial power, namely: investigation, prosecution, implementation of court decisions, and provision of legal services. This functional differentiation can result in law enforcement practices by law enforcement officials being fragmented and fragmentary (in accordance with their functions), because each component of law enforcement has different perceptions and meanings. This has an impact on the difficulty of realizing an integrated and integrated criminal justice system because there are often conflicts of interest and differences in interpretation among law enforcement components so that the products of the judiciary have not been able to meet the expectations of justice seekers.

7 The functional relationship can be carried out through correspondence media (P1-P21), so that all investigative activities are directed and monitored horizontally by the case research prosecutor through file correspondence not directly (on site).

8 This pre-prosecution is regulated in Article 139 of the Criminal Procedure Code (KUHAP), which reads: After the public prosecutor accepts or receives the results of a full investigation from the investigator, he immediately determines whether the case file meets the requirements to be able or not submitted to court.

9 Ichsan Zikry et al., Prapenuntutan Sekarang, Ratusan Ribu Perkara Disimpan, Puluhan Ribu Perkara Hilang: Penelitian pelaksanaan mekanisme prapenuntutan di Indonesia sepanjang tahun 2012-2014, Lembaga Bantuan Hukum Jakarta - MaPPI FHUI, 2. 
instructions if there are deficiencies. As a result, the investigation process only becomes the territory of the investigator and there is no check and balance in the exercise of that authority, which should be carried out by the public prosecutor as dominus litis or case controller. This situation will certainly have a direct impact on the rights of suspects and victims, because without checks and balances in the use of an authority, there will be wide open spaces for abuse of authority and or very large arbitrariness for investigators in carrying out investigations.

Regarding the terminology of this prosecution, it cannot actually be found in the substance of Article 1 of the Criminal Procedure Code which contains authentic interpretations. ${ }^{10}$ The term pre-prosecution can be found in articles governing the authority of the Public Prosecutor, namely Article 14 of the Criminal Procedure Code, where in paragraph $b$ of this article it is determined that as one of the authorities of the Public Prosecutor is to conduct a prosecution if there is a lack of investigation by taking into account the provisions of Article 110 paragraph 3, and paragraph 4, by giving instructions in the context of perfecting the investigation of the investigator. This means that in a general criminal act, if the Prosecutor considers that there is still a shortage in the results of the investigation conducted by the Police, then what he can do is called pre-prosecution.

The provisions of the substance in Article 14 letter $b$ of the Criminal Procedure Code, it is said that the Public Prosecutor has the authority to conduct pre-prosecution if there is a shortage in the investigation by giving instructions in order to improve the investigation of the investigator. The critical question in this regard is whether through such a work relationship arrangement does not create obstacles to the smooth process of criminal proceedings. Will it not actually slow down the settlement of a case?

Through the enactment of Law Number 16 of 2004 concerning the Attorney General's Office of the Republic of Indonesia, article 30, paragraph 1, letter $e$ of this law confirms that, in the Criminal field, the Prosecutor's Office has the duty and authority to complete certain case files and for that reason can carry out additional examinations before being handed over to the court which in its implementation is coordinated with the investigator. Provisions regarding the additional authority of the prosecutor's examination are new developments that raise questions about how much influence on the division of authority between the Police and prosecutors as stipulated in the Criminal Procedure Code and the work relations between the two agencies.

The existence of the pre-prosecution institution today, we might have to criticize, because the problem is that this pre-prosecution institution can cause ineffective law enforcement processes. It is very possible that the public prosecutor prosecuting a person (suspect) does not have in-depth knowledge of a case. This is because there is no active involvement of the public prosecutor in the investigation stage, and the limited understanding of a case is limited to the case file received from the investigator, which is not necessarily justified. Already a legal entity, the Indonesian criminal justice system, especially in the pre-trial phase, contains many structural problems.

The pre-prosecution institution in its development still has problems, so the purpose of the Criminal Procedure Code is to protect the dignity of every human being. Therefore, the purpose of justice in law is still a mere discourse of delusion. Reality in the field, the authors found that there are people who feel disadvantaged because of problems in this pre-prosecution submitting Judicial Review (JR) to the Constitutional Court (MK). ${ }^{11}$

${ }^{10}$ Authentic interpretation is an interpretation made by the legislators themselves, to a number of terms used in the Criminal Procedure Code.

11 "7 Hari Penyerahan Spdp Ke Penuntut Umum", Hukumonline.com, 11 January 2017, assessed 13 February 2020 - See at http: // www. hukumonline. Com / berita / baca / lt58763386dea5a / mk - tetapkan7-hari-penyerahan-spdp-ke-penuntut-umum. 
Provisions in Article 109 paragraph 1 of the Criminal Procedure Code that reads in the event that an investigator has begun an investigation into an event which constitutes a criminal offense, the investigator shall notify the prosecutor of this matter. Based on the decision of the Constitutional Court No. 130 / PUU-XIII / 2015 states Article 109 paragraph 1 is contrary to the 1945 Constitution and does not have binding legal force, unless interpreted as the investigator must inform and submit the SPDP of the investigation to the public prosecutor, the reported, and the victim/reporter within 7 days after the issuance of an investigation warrant.

The investigator has an obligation to notify and submit the SPDP to the public prosecutor, the reported party, and the victim/reporter, no later than 7 days after the issuance of an investigation warrant. Making the investigation process under the control of the public prosecutor and monitoring of the reported and victim/reporter. This means that the Constitutional Court's decision invites the values of reconstruction to present legal certainty for both the reported party and the reporter so that the case can be resolved as soon as possible in this decision. However, despite the Constitutional Court's ruling, there are still weaknesses in the prosecution process.

Another weakness, that the Police and the Prosecutors' Office is deemed not to have the ability to "coordinate", ${ }^{12}$ so that the files and suspects seem to be "taken in" means, the case was thrown here and there. In Andi Hamzah's perception, this practice is not in line with the essence of integrated criminal justice system. Ideally, since investigators issue SPDP, prosecutors have been intensely involved in assisting the investigation process, so that from the beginning the prosecutor has been able to monitor the weaknesses of the investigation process, or find out who else witnesses need to be questioned.

As a result of inadequate coordination between the police and the Prosecutors' Office, of course it can lead to cases of criminalization, "undue delay", life-long suspects, wrongful arrests, and the practice of "buying and selling" cases which are almost every day we hear in law enforcement in Indonesia. This is indeed caused by various factors, both the substance of the law, the structure, and also the culture of law enforcement officers. However, one thing that is certain from the emergence of these problems is due to the use of so much power and is not accompanied by effective control mechanisms over that power.

\section{Literature review}

The writing of this simple article is based on the paradigm of thought through the use of the Criminal Justice System (SPP) theory, Legal Certainty Theory, and Integrative Legal Theory, which carry the concept of reconstruction. ${ }^{13}$ In Remington and Ohlin's thinking, "The Criminal Justice System can be interpreted as the use of a system approach to the administration of criminal justice, and criminal justice as a system is the result of interactions between laws and regulations, administrative practices and social attitudes or behavior. Understanding the system itself contains the implications of processes that are prepared rationally and in an efficient way to provide certain results and with all its limitations".

Another case with Hagan distinguishes the notions of "criminal justice process" and "criminal justice system". Criminal justice process is every stage of a decision that confronts a suspect in the process that brings him to the criminal provisions for him, whereas the criminal justice system is an interconnection between each decision of every agency involved in the criminal

\footnotetext{
${ }^{12}$ RUU KUHAP Bakal Hapus Prapenututan, Hukumonline.com, 10 December 2017. Assessed 27 December 2017 at http://www. hukumonline.com/berita /baca /lt4b208a7dd85bc/prapenuntutan.

13 Romli Atmasasmita, Sistem Peradilan Pidana, Putra Bardin: Jakarta, 2002, 14.
} 
justice process. ${ }^{14}$ Mardjono Reksodiputro provides a limitation that what is meant by the criminal justice system (SPP) is, a crime control system consisting of police institutions, prosecutors, courts and prison inmates. ${ }^{15}$ On another occasion, Marjono stated that: "The criminal justice system is a system in a society to tackle the problem of crime. Tackling means here an attempt to control crime. In order to be within the limits of community tolerance, this system is considered successful if most of the reports and complaints of people who are victims of crime can be "resolved" by bringing the perpetrators to court and found guilty and get criminal."16

It was further stated that the objectives of the criminal justice system could be formulated as follows: "Preventing the public from becoming victims of crime; Resolving cases of crimes that occur so that the community is satisfied that justice has been upheld and the guilty convicted; and Make sure that those who have committed a crime do not repeat the crime again."

Regarding the Pre-Prosecution, it is an integral part of the Criminal Justice System (SPP), the meaning of the prosecution itself implicitly in the Criminal Procedure Code is defined in the Attorney General's Regulation Number Per-36 / A / JA / 09/2011, concerning Operational Standards for Procedures for Handling General Crimes Cases, namely as a public prosecutor's action to follow the progress of the investigation, after receiving notification of the start of the investigation from the investigator, study or examine the completeness of the case file of the investigation received by the investigator and provide instructions to be completed by the investigator, to be able to determine whether the case file is complete or not. Thus it can be concluded, both from the provisions in the Criminal Procedure Code and the Attorney General's Regulation, basically the prosecution is an act of the public prosecutor to: (1) following the development of the investigation; (2) receive case files; (3) studying and examining case files, and (4) providing instructions to investigators to complete case files. The entrance to the commencement of prosecution is to notify investigations carried out by investigators to the prosecutor or referred to as Notification of Commencement of Investigation (SPDP).

The legal objectives are theoretically namely justice, certainty, and expediency. ${ }^{17}$ The purpose of the law, has the first and foremost position than legal certainty and expediency. Historically, initially according to Gustav Radburch the goal of legal certainty was ranked highest above the other goals. However, after seeing the fact that with his theory in Germany under Nazi rule legalized the inhumane practices during World War II by making laws that validate the practices of war cruelty at that time.

The three elements (legal objectives) must be compromised, and must receive proportionally balanced attention. But in practice it is not always easy to work out a proportionally balanced compromise between the three elements. Without legal certainty, people do not know what to do and finally anxiety arises. But too much emphasis on legal certainty, too strict to obey the rule of law consequently rigid will cause a feeling of injustice.

The existence of legal certainty is a hope for justice seekers of the arbitrary actions of law enforcement officers who sometimes are always arrogant in carrying out their duties as law enforcers. Because with the existence of legal certainty the public will know the clarity of their rights and obligations according to law. Without legal certainty, people will not know what to do, do not know what is right or wrong, and what are prohibited or not prohibited by law.

\footnotetext{
14 Romli Atmasasmita, Ibid., 14.

15 Mardjono Reksodiputro, Op. cit., 1.

${ }^{16}$ Mardjono Reksodiputro, Op. cit., 84-85.

${ }^{17}$ Sudikno Mertokusumo, Mengenal Hukum: suatu Pengantar, Universitas Atma Jaya Yogyakarta: 2010, 161.
} 
This legal certainty can be realized through a good and clear naming in a law and its implementation will be clear. In other words, legal certainty means that the law is correct, the subject and the object and the legal threat. However, legal certainty might not be considered as an absolute element at all times, but the means used in accordance with the situation and conditions by taking into account the principles of benefit and efficiency.

Justice is one of the most discussed legal goals throughout the history of legal philosophy. The purpose of law is not only justice, but also legal certainty and legal usefulness. Ideally, the law must accommodate all three. Judges' decisions, for example, are as far as possible the resultant of the three. Even so, there are still those who argue that among the three legal objectives justice is the most important legal objective, some even argue, that justice is the only legal goal.

The benefit of the law needs to be considered because everyone expects a benefit in the implementation of law enforcement. Do not let law enforcement actually cause public unrest. Because when we talk about law, we tend only to look at the laws and regulations, which sometimes the rules are not perfect and not aspirational to people's lives. In accordance with the above principles, I am very interested in reading the statement of Satjipto Raharjo, which states that: justice is indeed one of the main values, but it is still beside others - something like utility and efficiency (doelmatigheid). Therefore, in law enforcement, the comparison between benefits and sacrifice must be proportional.

The final paradigm in the writing of this article is Integrative Legal Theory, understanding the law shows that to understand law holistically not only consists of "principles" and "rules", but must also include the institutions needed to "realize the rules" in reality. The four legal components, namely principle, rules, institutions, and processes work together integrally to bring these rules into reality, in the sense that the first legal development is done through written law in the form of laws and regulations. The four components of law that are needed to "realize the law" in reality, means legal development after going through legal reforms of jurisprudence. ${ }^{18}$ In the formation of law according to the criminal law system, according to Romli Atmasasmita in integrative legal theory, states the performance of BSE with the norm system, behavior system, and value system, can be explained:19

"Every step of the government in the formation of law and law enforcement is a policy based on a system of norms and logic in the form of principles and rules, and the normative power of law must be realized in changing people's behavior and bureaucracy towards the ideals of building a democratic rule of law. A democratic rule of law can be formed if it is consistently met with three pillars namely rule by law, protection of human rights, and access to justice."

The view of integrative legal theory is not only a basis for the study of national development problems in the context of inward looking, but also in the context of the influence of international relations into the life systems of a nation, especially the Indonesian nation. ${ }^{20}$ Therefore, in the practice of international relations in the midst of the globalization era, developing countries often become victims of hypocritical developed countries that are more selfish than the common progress of developing countries. Government actions are limited by law. Because according to integrative legal theory, the function of law as a means of renewal is not as a means of coercing the will of the authorities to its people (dark engineering), but as a modifier of the values that live in society towards new values that reflect legal certainty, usefulness and justice. In the field of bureaucracy, integrative legal theory requires the existence of bureaucratic engineering

18 Romli Atmasasmita, Teori Hukum Integratif, 90-91.

19 Romli Atmasasmita, Teori Hukum Integratif, Ibid., 97.

${ }^{20}$ Romli Atmasasmita, Teori Hukum Integratif, Ibid., 97. 
and community engineering. Bureaucratic engineering through norms and behavior systems, while community engineering is done through value systems. The three systems originated from the main source of the living law in their society, especially in Indonesia originating from the country's and nation's main source, Pancasila.

\section{Discussion}

Initially the establishment of the Prapuntutan institution is expected to be able to be a check and balance facility, but in reality, it has become one of the sources of problems in the Criminal Procedure Code itself. This condition is not too surprising because the process of establishing a pre-prosecution mechanism is indeed full of political interests. Daniel S. Lev once gave a picture of the formation of a pre-prosecuting institution that is full of the interests of power and is a reflection of the sectorial ego of law enforcement agencies. Stephen C. Thaman explained that in various parts of the world ideally the public prosecutor would always have control over the investigator or at least the course of the investigation. This is due to several reasons, one of which is to maintain checks and balances during the investigation stage, and also "patch" the shortcomings of investigators who in general are not equipped with sufficient legal knowledge. So that the active role of public prosecutors as controllers of investigations is expected to be able to minimize the abuse of authority and to streamline the law enforcement process. Therefore, through this research, the writer tries to look back on the current situation of the implementation of the pre-prosecution mechanism. This research will highlight several aspects that cause problems from the prosecution mechanism.

Reality shows the unwillingness of the investigator to be transparent and accountable in carrying out the authority of the investigation, by observing the tendency of the investigator to notify the investigation to the public prosecutor. Notification of the start of an investigation is the entrance of the pre-prosecution mechanism, and without the notification of the investigation, of course there will be no pre-prosecution mechanism. Without pre-prosecution, there is of course also no check and balance. In addition, this research also tries to see the effect of the implementation of the prosecution mechanism in the absence of an active role from the public prosecutor.

The current positive law regulates that, as in the Criminal Procedure Code, a case submitted by an investigator to the public prosecutor in the prosecution process can take more than 6 (six) months. The lowest point of this problem is, the regulation itself, KUHAP is weak so that it has the potential to cause different interpretations. Differences in interpretation between investigators and prosecutors in the pre-prosecution process will slow the process of handling a case, so that it can cause a case to be protracted. Criminal procedural law that prevailed in Indonesia before the Criminal Procedure Code (KUHAP) was Het Herziene Inlandsch Regulation (HIR) as a legacy from the Dutch colonial. After HIR it is in Indonesia Law No. 1 Drt. In 1951 several articles contained criminal procedure. The formulation of the criminal procedure code in the HIR is no longer in accordance with what is mandated in the Pancasila and the 1945 Constitution. ${ }^{21}$ Cultural differences between Indonesia and the Netherlands, of course, also resulted in incompatible contents of the adoption regulations with the aspirations of national law.

${ }^{21}$ Pancasila is the ideal foundation of the Indonesian nation, the term ideology comes from the word "idea", which means concept ideas, basic understandings, ideals, and logos which means knowledge. The word idea comes from the Greek, "eidos" which means form. Beside that there is the word "idein" which means "look". So literally, ideology means the knowledge of ideas (science of ideas) or the teachings of basic understandings. Meanwhile, the substance of the 1945 Constitution is the constituent foundation of the State of Indonesia as a state of law. The rule of law is a doctrine in the science of law that began to emerge in the $19^{\text {th }}$ century in Europe, along with the birth of a constitutional and democratic state. The rule of law is a translation of the rule of law or rechtstaat. 
Realizing this difference, the Indonesian government made a legal reform by changing the Indonesian criminal procedure code by revoking the criminal procedure law provisions contained in the HIR (Saatsblad, 1941, Number 44) and then declaring the enactment of Law No. 8 of 1981 concerning Criminal Procedure Law on 31 December 1981 (State Gazette Number 76 of 1981) concerning the Criminal Procedure Code. ${ }^{22}$

In relation to the prosecution, there are currently many problems which not less invite legal experts to do criticism. In the functional relationship between the police and prosecutors, as law enforcement officers, which often causes problems is the implementation of prosecution. Normatively, the problem arises from the weakness in the Criminal Procedure Code regarding preprosecution. One of these weaknesses is the issue of submitting and perfecting case files. This weakness is seen in the coordination of tasks between the investigator and the public prosecutor in compiling case files. The coordination is clearly stated in the following articles:

1. Article 8 paragraph 3 - Submission of case files as referred to in paragraph 2 is carried out: In the first stage the investigator only submits case files; In the event that the investigation is deemed completed, the investigator hands over responsibility for the suspect and evidence to the public prosecutor;

2. Article 110 paragraph 2 and paragraph 3 - Paragraph 2: In the event that the public prosecutor believes that the results of the investigation are still incomplete, the public prosecutor immediately returns the case file to the investigator accompanied by instructions to be completed;

3. Paragraph 3 - In the event that a public prosecutor returns the results of an investigation to be completed, the investigator must immediately conduct additional investigations in accordance with the instructions of the public prosecutor;

4. Article 138 paragraph 2 - In the case that the investigation is incomplete, the public prosecutor returns the case file to the investigator with instructions on what must be done to be completed and within fourteen days from the date of receipt of the file, the investigator must have returned the case file to the public prosecutor.

That is, if the case file has been received by the public prosecutor, but the public prosecutor views the case file as incomplete or incomplete or lacks of evidence, the public prosecutor immediately returns the case file to the investigator accompanied by notes or instructions about what must be done by the investigator so that the case file is complete. This process is referred to as pre-prosecution, whose arrangements are contained in Article 138 paragraph 2 of the Criminal Procedure Code. The term of prosecution can be found in Article 14 letter $b$ of the Criminal Procedure Code concerning the authority of public prosecutors.

Other problems related to the prosecution are the following: ${ }^{23}$

1. With no limit on the number of times the submission or re-submission of case files is reciprocally from the investigator to the public prosecutor or vice versa, it is always possible that, based on the opinion of the prosecutor, the results of the

${ }^{22}$ The Department of Justice of the Republic of Indonesia, 1982, Guidelines for Implementing the Criminal Procedure Code, the Attorney General's Office of the Republic of Indonesia, p. 1981. The law is based on the provisions of Article 285 referred to as the "Criminal Procedure Code", or in judicial practice commonly abbreviated with the term Criminal Procedure Code. Since its enactment, many people have "praised" the Criminal Procedure Code by calling it a "masterpiece" of the Indonesian people, but there are also those who argue that the law called "the book" is not quite right. The codification should be named after the book. So, it should: "This codification is named after the Criminal Procedure Code." Not the law called "the book" but the codification. Read more: Andi Hamzah, Hukum Acara Pidana Indonesia, Edisi Revisi, Penerbit Sinar Grafika, Jakarta, 2005, 1.

23 Keputusan Menteri Kehakiman Republik Indonesia Nomor: M.01.PW.07.03 Tahun 1982, Field of Investigation, Chapter III, item 4. 
investigator's additional investigation have not been completed, the case file can be protracted pacing from the investigator to the public prosecutor or vice versa;

2. Furthermore, if it is related to the time limit as specified in Article 138 paragraph 2 , where within fourteen days from the date of receipt of the investigator's file must have completed the results of the investigation in accordance with the instructions of the public prosecutor. If during this time the investigator has not succeeded in completing the results of the investigation or additional investigations in accordance with the instructions of the public prosecutor, whether the investigator must immediately return the case file back in an incomplete condition or continue to be sought by the investigator to be completed, even though the time limit has been passed.

On the basis of the functional relationship between the Police Investigator and the Prosecutor's Office, the impact on economic values in correspondence has an impact on the back and forth ${ }^{24}$ of the file cases between investigators and prosecutors / case prosecutors. This means that from the economic aspect, such reality is ineffective and inefficient, while from the aspect of the legal certainty that the lack of formal case files and legal evidence collected by investigators will weaken the evidence and prosecution activities in the court. Whereas the prosecutor will assume a great responsibility in proving his indictment and convincing the judge that there is a criminal offense, there is a culprit, covering up mistakes, there is evidence and evidence then there is a reason for forgiveness and justification, so the perpetrator must be punished for responsibility.

The value of justice from this lack of completeness can lead to misguided justice which punishes innocent people ("miscarriage of justice"). Whereas the functioning of the Indonesian Criminal Justice System must not be separated from the spirit of the Second Precepts namely "Humanity that is just and civilized" and "Fifth, namely Social Justice for All Indonesian People". Then also must heed Article 28D paragraph 1 of the 1945 Constitution of the Republic of Indonesia which states: "Every person has the right to recognition, guarantees, protection, and certainty of the law just and equal treatment before the law" and must also pay attention to the principle of legal justice intended in Article 24 paragraph 1 of the 1945 Constitution of the Republic of Indonesia: "Judicial power is an independent power to administer justice to enforce law and justice".

As a more humane step, projections of reconstruction in the pretreatment must be carried out progressively, integratively and systematically. Why should a pre-prosecution institution be reconstructed? Because in practice, the return of cases can occur several times, even the investigation process marked by the submission of Notice of Commencement of Investigation (SPDP) is not mandatory, often not submitted to public prosecutor. The phenomenon of alternating case files between investigators and public prosecutors occurs because of the limited role of public prosecutors in the case investigation process.

As a more humane step, the public prosecutor should also have the authority in the process of investigating a case because the prosecutor will conduct the prosecution in court. Not directly proportional, the current reality, the investigation process is only the authority of the investigator. The public prosecutor does not have the authority to control or oversee how the investigation process works. So, as a result the Prosecutor did not know whether the investigation process was in accordance with the procedure or not.

24 The term "back and forth" is actually not known in the Criminal Procedure Code, but the term back and forth case file is already commonly used at the time of the prosecution of a case. The case files go back and forth because each has a logical and justifiable argument, but it is not necessarily accountable. Returning case files from the public prosecutor to be corrected by the investigator in accordance with the instructions given by the public prosecutor is sometimes difficult for the investigator to fulfill because they may be seen as making it up, and outside the context of the case. 
The value of legal certainty becomes abnormal, when the article also does not clearly stipulate the limit on the number of times the case file can be returned from the public prosecutor to the investigator or vice versa. So, this can be called a violation of Human Rights. The ambiguity of the meaning regarding this matter, concerning this limit, will cause or potentially violate the rights of the suspect while opening up the practice space for abuse of authority by law enforcement officials. Why not, because the rules don't necessarily regulate how long the pre-prosecution period is.

The alternating case between the investigator and the public prosecutor actually has a solution with the agreed mechanism, if the police investigator is unable to develop his investigation then the investigator states that the investigation is optimal, and then the public prosecutor uses the mechanism in Law No. 16 of 2004 concerning the Attorney General's Office Article 30 paragraph 1 letter $d$, namely conducting additional examinations. The problem is that this additional audit authority is limited to both the object of examination and the time, so that in the end the practice cannot be carried out optimally.

To overcome the back and forth case files from the investigator to the public prosecutor, so once the investigator has begun to conduct an investigation, the investigator informs him that an investigation has been carried out to the prosecutor's office and then the prosecutor's office in addition to sending P.16 to the investigator also conveyed that the investigator in the case was able to coordinate at any time with the P.16 prosecutor so that the investigator and the P.16 prosecutor can immediately coordinate during the pre-prosecution. Because with the enthusiasm and willingness to coordinate both juridical and non-juridical, a good relationship will be created and can be of one view in the case and will eliminate the selfish values between investigators and prosecutors in carrying out a law enforcement process.

The coordinating relationship between investigators and public prosecutors is very important because it will have an impact on the handling of criminal cases themselves, especially at the pre-prosecution stage. For this reason, it is necessary to build an integration system between investigators and public prosecutors at the pre-prosecution stage.

Difficult to grow the value of justice, legal certainty in the pre-prosecution institution for justice seekers. One of them is due to an error/misconception in designing the relationship between investigators and public prosecutors at the Criminal Procedure Code. The relationship between investigators and public prosecutors in the Criminal Procedure Code, in principle is based on the principle of functional differentiation which is a foothold in the relationship between subsystems/agencies that are in the Criminal Procedure Code.

The above description further confirms that the pre-prosecution institution is not prepared in design to bridge the investigation and prosecution, but is only a "win-win solution" between the investigating institution (the police) and the prosecution (the prosecutor). That is, the concept of pre-prosecution is an agreement. The author views the weakness of the prosecution, also caused by mistakes in understanding Article 110 and Article 138 of the Criminal Procedure Code, so as if the investigator and the public prosecutor were in a different room, then related to the prosecution mechanism. That is what causes the problem of alternating case files or not the completion of a case file at the pre-prosecution stage. If the framework of this misconception is maintained, it will create an ineffective criminal justice system.

Criminal Procedure Code sees currently the prosecution is placed as an "ending process" of the investigation. As a preliminary analysis of this simple research, that by using the theory of progressive legal reconstruction, this pre-prosecution institution, apparently will not solve the problem of cohesiveness between investigators and public prosecutors. This is because the investigator in conducting the investigation process uses an approach with a field implementation framework. After the investigation is complete, the results of the investigation 
with the approach used by the investigator, then appear to be "tested" by the public prosecutor with a jurist's approach.

The consequence is that many cases will not be synchronized, because between the point of view of the investigator and the point of view of the prosecutor using different glasses. Then for the discrepancy in the results of the investigation, the prosecutor asked the investigator to complete the investigation with the viewpoint of the public prosecutor. Furthermore, this is a problem that arises, apparently the instructions given by the public prosecutor will overhaul many of the results of the investigation, while the time given according to Article 138 of the Criminal Procedure Code is only 14 days. How is it possible for the investigator to complete according to the wishes of the public prosecutor and suddenly change the results of the investigation with an approach similar to a public prosecutor, in which the investigation has been prepared so long with the investigator approach model?

What happened, with this inconsistency, led to many cases which were ultimately difficult for investigators to complete and ultimately the victims who were harmed? According to the author, this incident was caused by a misunderstanding of the relationship between the investigator and the public prosecutor who seemed to negate each other not to complement each other. Certainly, the value of legal certainty in this case is starting to melt again, as if there is no just law.

\section{Conclusion}

The results of this study are quite broad dimensions, namely how to reconstruct preprosecution institutions to fit the values of certainty and fairness. Relationships and constructive communication between law enforcement officers, in this case the police and the prosecutors' Office, must be in harmony. Indeed, the law is for the benefit of the community, the relationship between the two law enforcement agencies must be built through integrated communication. That is, in an ideal concept, the public prosecutor cooperates with the investigator since the start of an investigation. So that the different approaches between investigators and prosecutors have been elaborated since the beginning of the investigation. Or it can be said that the relationship between investigators and public prosecutors is a communication space, not like a post box between investigators and public prosecutors.

If good relations through building communication can take place, then the examination of case files back and forth becomes unnecessary, because the investigator and the public prosecutor already have a harmonized view and need for proof. Reconstruction in the future is to fix the rules as the basis for norms in pre-prosecution institutions. So that the implementation of the investigation, the two can complement each other, no need to wait until the end of the investigation process which is only limited to 14 days.

As a more actual step is the implementation of the relationship between the prosecutor and the ideal investigator conceptually can be implemented, if the subsystems are not limited by the boundaries of subsystems (functional differentiation). In the future, if the barriers between subsystems are not interpreted by clarifying each function (investigation), it will become possible for the public prosecutor to be involved from the beginning of the investigation. This conception will not work with the current Criminal Procedure Code, because the Criminal Procedure Code does not have a public prosecutor involved in the investigation stage, and the possibility of a public prosecutor being involved only in the pre-prosecution stage, which is the ending process of the investigation.

The value of legal certainty and justice in the pre-prosecution institution can be realized, if there is no difference in function in the law enforcement agency between the authority of the investigator and the public prosecutor. The authority of investigators and prosecutors must 
be integrated. The concept of integration between investigators and prosecutors is the solution of legal reconstruction offered from the results of this study. Because the conception of the existence of a box of authority makes many human rights violations occur.

\section{Acknowledgements}

This research did not receive any specific grant from funding agencies in the public commercial, or not-for-profit sectors.

The author declares no competing interests.

\section{References}

Anwar, Y., \& Adang (2008). Pembaharuan Hukum Pidana [Criminal law reform]. Jakarta: PT Gramedia Widiasarana.

Atmasasmita, R. (2002). Sistem Peradilan Pidana [Criminal Justice System]. Jakarta: Putra Bardin.

Effendi, T. (2013). Sistem Peradilan Pidana: Perbandingan Komponen dan Proses Sistem Peradilan Pidana di Beberapa Negara [Criminal Justice System: Comparison of components and processes of the criminal justice system in several countries]. Yogyakarta: Pustaka Yustisia.

Hamzah, A. (2010). Hukum Acara Pidana Indonesia [Indonesian Criminal Procedure Law]. Jakarta: Sinar Grafika.

Mertokusumo, S. (2010). Mengenal Hukum: suatu Pengantar [Know the law: An introduction]. Universitas Atma Jaya Yogyakarta.

- (2012). Teori Hukum Integratif: Rekonstruksi Teori Hukum Pembangunan \& Teori Hukum Progresif [Integrative Legal Theory: Reconstruction of Development Law Theory and Progressive Legal Theory]. Yogyakarta: PT. GentaPublishing.

Rozi, R. M. (2017). Revitalisasi Lembaga Pra Penuntutan Guna Menyokong Kepastian Hukum \& Keadilan Dalam Sistem Peradilan Pidana Indonesia [Revitalization of pre-prosecution institution to support legal certainty and justice in the criminal justice system in Indonesia]. Rechvinding, 6(1).

Sutherweim (1991). Dwi Windu Sejarah Kejaksaan [Dwi Windu Attorney General's history]. Jalarta: Kejaksaan RI.

Zikry, I. et al. (n.d.), Prapenuntutan Sekarang, Ratusan Ribu Perkara Disimpan, Puluhan Ribu Perkara Hilang: Penelitian pelaksanaan mekanisme prapenuntutan di Indonesia sepanjang tahun 2012-2014 [Pre-prosecution now, hundreds of thousands of cases saved, tens of thousands of cases missing: Research on the implementation of the prosecution mechanism in Indonesia during 2012-2014]. Lembaga Bantuan Hukum Jakarta - MaPPI FHUI. 